\title{
An international comparison of incentives for earnings management in order to meet analysts forecasts
}

\author{
Susana Callao Gastón ${ }^{a}$, José Ignacio Jarne Jarne ${ }^{b}$ \\ a, b)Department of Accounting and Finance, Faculty of Economics and Business, University of Zaragoza. Zaragoza, España.
}

\begin{tabular}{ll}
\hline \multicolumn{2}{c}{ borresponding author. } \\
E-mail address: jijarne@unizar.es \\
A R T I C L E I N F O
\end{tabular}

(C)2021 ASEPUC. Published by EDITUM - Universidad de Murcia. This is an open access article under the CC BY-NC-ND license (http://creativecommons.org/licenses/by-nc-nd/4.0/).

Keywords:

Earnings management

Analysts forecast

Stock markets

Incentive to manage earnings

International comparison

Una comparación internacional del incentivo para manipular el resultado con el objetivo de alcanzar los pronósticos de los analistas

R E S U M E N

\section{Códigos JEL:}

M40

M41

G17

Palabras clave:

Manipulación del resultado

Pronósticos de los analistas

Mercados bursátiles

Incentivos a manipular

Comparación internacional
Investigaciones previas han evidenciado que cuando los resultados alcanzan, o superan, los pronósticos de los analistas, el mercado reacciona positivamente, mientras que, cuando dichos pronósticos no son alcanzados, la reacción del mercado es la contraria. Por ello, los pronósticos se convierten en metas a batir y, tal como la literatura ya ha contrastado, surge un incentivo para la manipulación del resultado. En este contexto, el presente trabajo va más allá, evidenciando que la reacción positiva o negativa es de diferente magnitud según los mercados y que ello explica que la fuerza con la que las empresas perciben el incentivo a manipular los resultados para alcanzar dichos pronósticos también sea diferente según el mercado en el que cotiza. Comparando seis mercados, obtenemos que el incentivo es más potente cuanto mayor es el premio por cumplir los pronósticos, o la penalización por no hacerlo.

(C)2021 ASEPUC. Publicado por EDITUM - Universidad de Murcia. Este es un artículo Open Access bajo la licencia CC BY-NC-ND (http://creativecommons.org/licenses/by-nc-nd/4.0/). 


\section{Introduction}

Earnings announcements are very important events for investors because, when they take place, investors can know whether the company's actual earnings match analysts' forecasts. Meeting (failing to meet) these forecasts has a positive (negative) impact on the company's stock prices and return, as found by Edmonds, Edmonds, Fu, and Jenkins (2018), Kinney, Burgstahler, and Martin (2002), López and Rees (2002) and Skinner and Sloan (2002), among others. This is why forecasts are an important target to reach and, like other targets, meeting forecasts may be an incentive for earnings management. The link between analysts' forecasts and earnings management has been highlighted in several studies, including those by Abarbanell and Lehavy (2003a, 2003b), Burgstahler and Eames (2006), Callao and Jarne (2018), Cheng and Warfield (2005), Das and Zhang (2003), Dechow, Ge, and Schrand (2000), Matsumoto (2002), Payne and Robb (2000) and Plummer and Mest (2001).

We think that the impact of meeting or failing to meet earnings forecasts on the stock return - that is, the magnitude of the reward for meeting forecasts or the penalty for not doing so-may differ between stock markets and that the strength of the incentive for earnings management in order to meet forecasts may be linked to the magnitude of the reward or penalty. These topics have not been investigated until the present paper.

We consider six indexes that represent six stock markets that are located in different geographic areas and that have different characteristics (legal origin, financial development, analysts following the companies, accuracy of the forecasts and gross domestic product GDP per capita). These aspects may influence the markets' response to compliance or noncompliance with forecasts as well as firms' attitudes regarding earnings management. The six indexes are Bovespa (Brazil), DAX (Germany), Dow Jones (US), FTSE (UK), Hang Seng (Hong Kong) and IBEX (Spain).

Our results show that the magnitude of the market reaction (i.e. the reward or punishment) differs between markets. A code law system, less financial development and less wealth drive greater market reactions. In addition, the market reaction increases when the number of analysts following a firm increases and when these analysts forecast with more accuracy. Furthermore, our results show that the magnitude of the market reaction explains differences in the strength of the perceived incentives for companies to perform earnings management to meet forecasts. The greater the reward or penalty, the stronger the incentive for earnings management. That is, when meeting forecasts has a higher impact on the stock return, there is a higher probability that a company will manage its earnings to meet forecasts.

Previous studies have highlighted the importance of earnings management in listed companies (see, for example, Dichev, Graham, Harvey, \& Rajgopal, 2016). Our study contributes to the literature on earnings management and its impact on the stock market. First, the results of an international comparison reveal differences in the magnitude of the market's reward for meeting forecasts. Second, the results show that the incentive to manage earnings in order to meet forecasts is not independent of the market in which the company is listed.

The results we obtained may be useful for investors, auditors, analysts and capital markets in general, as they provide information about the process that is set in motion when analysts' earnings forecasts are published and how this can influence the reliability of financial information. Investors and analysts may find our results particularly useful when interpreting financial information to make investment decisions or create forecasts and recommendations. The findings indicate that auditors should be more vigilant in their work for firms listed in stock markets, for which the incentive to manage earnings is greater due to the market's stronger reaction when these firms meet or fail to meet forecasts.

The next section reviews the literature on this issue. Section 3 describes the sample, and Section 4 explains the methodology. In Section 5, we collate the results. Section 6 presents our sensitivity analysis, and in Section 7, we discuss the relevant conclusions we can draw from the results.

\section{Literature review}

Financial analysts' opinions and recommendations regarding investors and their investment decisions have an important impact on the share prices of listed companies. Analysts' forecasts are highly relevant to investors, companies and the market in general, because, as Larrán and Rees (1999) state, they represent an approximation of the market's expectations for the company.

When a company's actual earnings are announced and the market knows whether it met its earnings forecast, the company's share prices will change. Previous studies (e.g. Bartov, Givoly, \& Hayn, 2002; Edmonds et al., 2018; Kasznik \& McNichols, 2002; Kinney et al., 2002; López \& Rees, 2002; Skinner \& Sloan, 2002) have analysed these market reactions and found that a negative adjustment to share prices occurs when earnings fail to meet forecasts and a positive one occurs when earnings meet or exceed forecasts. In absolute terms, the penalty for failing to meet forecasts is significantly greater than the reward for exceeding them. In addition, firms that continuously meet expectations are valued more highly than those that only meet them occasionally (Bartov et al., 2002; Kasznik \& McNichols, 2002; López \& Rees, 2002). This market behaviour justifies the fact that earnings forecasts are becoming goals for companies to meet.

Analysis of the evolution of earnings over time revealed a decreasing tendency to report earnings that fall slightly short of analysts' forecasts and an increasing tendency towards positive earnings deviations (Barua, Hoon, \& Yi, 2019; Brown, 2003; López \& Rees, 2002). When there is a goal to be met, such as earnings forecasts, there is an incentive to manage earnings when non-managed earnings do not meet the goal (Caneghem, 2002; Embong \& Hosseini, 2018; García Osma, Gill de Albornoz, \& Gisbert, 2005; Niskanen \& Keloharju, 2000) ${ }^{1}$. Previous studies examining the link between earnings forecasts and earnings management have provided evidence that earnings are managed upward to meet earnings forecasts (Callao \& Jarne, 2018; Dechow et al., 2000; Matsumoto, 2002; Payne \& Robb, 2000; Zhang, Perols, Robinson, \& Smith, 2018). In addition, it has been found that companies manage earnings to meet earnings forecasts, but showing slight positive earnings deviations (Abarbanell \& Lehavy, 2003b; Cheng \& Warfield, 2005).

To date, the literature has examined the impact of meeting or failing to meet earnings forecasts on the market, including rewards and punishments for the company. The results have shown that meeting forecasts is a goal for companies and this leads to an incentive for earnings management. However, studies have not investigated whether the magnitude of

\footnotetext{
${ }^{1}$ The incentives to manage earnings that have been studied in the literature include, among others, those related to debt contracts, management remuneration, tax effects and earnings benchmarks (positive earnings, positive earnings variation, earnings forecasts).
} 
the reward (penalty) for meeting (failing to meet) forecasts differs between markets or, if so, the implications of these differences on the probability of feeling an incentive to manage earnings. The present work aims to help fill this gap.

The markets under study are located in different geographic areas, in countries with different legal systems, levels of financial development, wealth, different numbers of analysts following companies and different manners of working. A priori, it is expected that comparison of markets with different characteristics will reveal differences in the magnitude of rewards/penalties between markets. If this is the case, we think that companies are more likely to feel an incentive to manage earnings in order to meet forecasts when they trade in markets in which the magnitude of the reward for meeting these forecasts, or the penalty for not doing so, is higher.

Based on this, we formulated and tested the following hypotheses, stated in the alternate form:

$\mathbf{H}_{1}$ : There are significant differences between markets in the magnitude of the reward (penalty) for meeting (failing to meet) earnings forecasts.

$\mathbf{H}_{2}$ : The magnitude of the reward (penalty) offered by the market for meeting (failing to meet) earnings forecasts influences the probability that companies will perceive an incentive to manage earnings.

\section{Sample}

To test $\mathrm{H}_{1}$ and $\mathrm{H}_{2}$, we created a sample composed of companies listed in six stock indexes: Bovespa, DAX, Dow Jones, FTSE, Hang Seng and IBEX. In total, we identified 306 companies $^{2}$, but after removal of 82 financial companies, the final sample was comprised of 224 companies. The period of analysis covers the years from 2006 to 2015, providing us with 2,240 observations. The market distribution of these observations is presented in Table 1 .

Table 1

Sample

\begin{tabular}{lrrr}
\hline INDEX (Country) & Firms in the index & Firms in the sample & $\begin{array}{r}\text { Observations } \\
\text { 2006-2015 }\end{array}$ \\
\hline BOVESPA (Brazil) & 61 & 44 & 440 \\
DAX (Germany) & 30 & 24 & 240 \\
DOW JONES (US) & 30 & 25 & 250 \\
FTSE (UK) & 100 & 77 & 770 \\
HANG-SENG (Hong Kong) & 50 & 28 & 280 \\
IBEX (Spain) & 35 & 26 & 260 \\
TOTAL & 306 & 224 & 2,240 \\
\hline
\end{tabular}

Working with these indexes, we will be able to compare markets that are located in different geographic areas and that have different characteristics, which may influence their response to compliance or non-compliance with forecasts as well as firms' attitudes regarding earnings management. Specifically, we considered the following aspects: legal origin (common law or code law), level of financial development (low, medium, high), number of analysts following the companies, accuracy of forecasts and GDP per capita. Table 2 shows these aspects of the different countries and markets.

As shown in the table, we included three code law countries (Germany, Spain and Brazil), which have a greater need

\footnotetext{
${ }^{2}$ Sixty-one companies from the Bovespa Index, 30 from the DAX, 30 from the Dow Jones, 100 from the FTSE, 50 from the Hang Seng Index and 35 from the IBEX.
}

Table 2

Characteristics of the markets and countries

\begin{tabular}{|c|c|c|c|c|c|c|}
\hline INDEX & Country & Legal origin $^{1}$ & $\begin{array}{l}\text { Financial } \\
\text { develop. }^{2}\end{array}$ & $\begin{array}{l}\text { Analysts } \\
\text { following } \\
\text { (mean) }^{3}\end{array}$ & Accuracy ${ }^{4}$ & $\begin{array}{l}\text { GDP per } \\
\text { capita }^{5}\end{array}$ \\
\hline BOVESPA & Brazil & Code & -0.32 (low) & 10.56 & 0.55 & 11,080 \\
\hline DAX & Germany & Code & 0.95 (med) & 25.82 & 0.42 & 42,970 \\
\hline DOW JONES & US & Common & 1.44(high) & 21.59 & 0.12 & 49,593 \\
\hline FTSE & UK & Common & 0.96 (med) & 14.39 & 0.36 & 40,049 \\
\hline HANG-SENG & Hong Kong & Common & & 20.03 & 0.40 & 33,030 \\
\hline IBEX & Spain & Code & 0.49 (med) & 20.56 & 0.51 & 30,701 \\
\hline
\end{tabular}

${ }^{1}$ Taken from Djankov et al. (2007). Code (Common) indicates a code-law (commomlaw) country

2 As in Degeorge et al. (2013), the level of financial development is measured by Finance-Aggregate (Beck \& Levine, 2002)

${ }^{3}$ It is the mean of analysts following the companies listed in the Index from 2006 to 2015 (data from I/B/E/S)

${ }^{4}$ It is the mean of the absolute difference between actual earnings and earnings forecast scaled by earnings forecast for companies listed in the Index from 2006 to 2015 (actual earnings from DATSTREAM and earnings forecast from I/B/E/S)

${ }^{5}$ It is the mean of Gross Domestic Product (GDP) per capita in \$ USA from 2006 to 2015 (data from World Bank)

for protection and state control over law enforcers (Siems, 2007). The other three countries (the US, the UK and Hong Kong) have common law countries in which the legal system relies on judges' decisions rather than strict codes.

We selected countries with different levels of financial development, measured by the finance aggregate variable developed by Beck and Levine (2002) and used by Degeorge et al. (2013). Specifically, we considered countries with the highest level of financial development (US), a medium level of development (UK, Germany and Spain) and a low level of development (Brazil) ${ }^{3}$.

The number of analysts following companies also differs between markets. From 2006-2015, the average ranged from 10 analysts in the Brazilian market to more than 25 in the German market.

Forecast accuracy is measured by the deviation of actual earnings from the earnings forecast. Thus, lower deviation means higher accuracy. In our sample, based on the companies listed in the indexes under study, the markets with a higher degree of forecast accuracy are US and UK, and those with lower accuracy are Spain and Brazil.

Finally, the sample is comprised of markets located in countries with different levels of economic development, measured by GDP per capita. From 2006-2015, this ranged from $\$ 11,000$ (Brazil) to almost $\$ 50,000$ (US).

\section{Methodology}

This section describes the methodology we employ in the study. First, we test $\mathrm{H}_{1}$ : there are significant differences between markets in the magnitude of the reward (penalty) for meeting (failing to meet) earnings forecasts. The variables used to test $\mathrm{H}_{1}$ are defined in Annex 1 .

To measure the magnitude of the reward (penalty) for meeting (failing to meet) earnings forecasts, we examine the cumulative abnormal return (CAR) around the earnings announcement date, when the earnings deviation from the forecast is known ${ }^{4}$. The variable we use is the mean of the absolute $C A R$ values of the shares listed in each market in a \pm 1 window around earnings announcement date. We use absolute values of CAR because we aim to quantify the market's

\footnotetext{
${ }^{3}$ Hong Kong is not included in Beck and Levine's (2002) variable.

${ }^{4}$ Cumulative abnormal return has been used in previous research to measure the impact of an event on the stock return (see Bartov et al., 2002; Kinney et al., 2002; López \& Rees, 2002; Skinner \& Sloan, 2002).
} 
reward (in which case $C A R$ would have a positive value) or penalty (in which case $C A R$ would have a negative value). Annex 2 shows how the (mean $|C A R|$ ) variable is computed. The data are obtained from Datastream (actual data) and I/B/E/S (forecasted data).

To test $\mathrm{H}_{1}$, we use the Kruskal-Wallis non-parametric test (Kruskal \& Wallis, 1952) since the results of the KolmogorovSmirnov and Shapiro-Wilk tests (Kolmogorov, 1933; Shapiro \& Wilk, 1965; Smirnov, 1939) showed that the variable mean $|C A R|$ does not follow a normal distribution (Table 3). We also test the significance of differences in this variable for market pairs using the non-parametric Mann-Whitney test (Mann \& Whitney, 1947).

Table 3

Results from Normality tests

\begin{tabular}{lccccccc}
\hline \multirow{2}{*}{ Variable } & \multicolumn{3}{c}{ Kolmogorov-Smirnov } & \multicolumn{3}{c}{ Shapiro-Wilk } \\
& Statistic & df & Sig. & Statistic & df & Sig. \\
\hline mean | CAR | & 0.081 & 2240 & 0.000 & 0.960 & 2240 & 0.000
\end{tabular}

mean $|C A R|$ is defined as the mean of the absolute values of cumulative abnormal return in a $-1+1$ window around the earnings announcement date for firms listed in the indexes under study. It measures the reward (or penalty) for meeting (or failing) to meet earnings forecasts.

To explain differences in the markets' reactions to companies meeting or not meeting earnings forecasts, we perform a regression (equation 1 ) in which mean $|C A R|$ is the dependent variable and the explanatory variables are those considered relevant for the sample selection:

$$
\begin{aligned}
\operatorname{mean}\left|C A R_{j t}\right|= & \alpha_{0}+\alpha_{1} L E G_{j}+\alpha_{2} \text { FINDEV }_{j}+\alpha_{3} A F O L L_{i t} \\
& +\alpha_{4} A C C_{i t}+\alpha_{5} l G D P_{j t}+e_{i t}
\end{aligned}
$$

where:

mean $\left|C A R_{j t}\right|$ is the dependent variable, which quantifies the average reward (penalty) in market $j$ during period $t$ for meeting (failing to meet) earnings forecasts. It is defined as the mean of the absolute $C A R$ values in a \pm 1 window around the earnings announcement date for firms listed in index $\mathrm{j}$ in period $\mathrm{t}$

$L E G_{j}$ is a dichotomous variable representing the legal system of country $j$, which takes a value of 0 for a common law system and a value of 1 for a code law system, in line with the classification proposed by Djankov, McLiesh, and Shleifer (2007).

$F I N D E V_{j}$ measures the level of financial development for country $j$ based on the finance aggregate variable developed by Beck and Levine (2002).

$A F O L L_{i t}$ is the number of analysts following company $i$ in period $t$ (data extracted from I/B/E/S).

$A C C_{i t}$ is the absolute difference between actual earnings and an earnings forecast scaled by the earnings forecast for company $i$ in period $t$ (actual data extracted from Datastream and forecasted data extracted from I/B/E/S).

$l G D P_{j t}$ is the logarithm of GDP per capita for country $j$ in period $t$ (data obtained from World Bank).

Below, we explain the variables used in the regression as well as the expected signs regarding the relationship between the independent variables and the dependent one.

Dependent variable (mean $\left.\left|C A R_{j t}\right|\right)$ : This variable is defined as the mean of the absolute values of the cumulative abnormal return of the shares listed in a certain market in $\mathrm{a} \pm 1$ window around earnings announcement date, when it is known whether a company's earnings met the forecasts. It measures the average reward (penalty) in market $j$ during period $t$ for meeting (failing to meet) earnings forecasts. The variable is calculated for each studied year according to the process explained in Annex 2.

Explanatory variables: We introduce five explanatory variables in the model:

- Legal origin ( $L E G)$ : Code law systems follow the Roman legal tradition, which is characterised by fact-finding conducted by state-employed judges, automatic review of decisions and reliance on codes rather than judicial discretion. In contrast, common law systems rely on fact-finding by juries, independent judges, infrequent appeals and flexible codes.

Investors in code law countries usually rely on financial reporting regulated by law, and analysts' forecasts could be less valued than in common law countries. Thus, we could expect a weaker market reaction to meeting or failing to meet earnings forecasts in code law countries; that is, we could expect the sign for the coefficient of $L E G$ to be negative. On the other hand, code law countries feature less of a stock market tradition than common law countries and investors have fewer decision tools, giving greater value to accessible tools like analysts' forecasts. This would cause the market reaction to be greater and the expected sign of the coefficient of $L E G$ to be positive. Consequently, we are not able to predict the sign of the relationship between $L E G$ and the dependent variable.

- Financial development (FINDEV): This variable is based on the finance aggregate variable (Beck \& Levine, 2002). It is a measure of the degree to which national financial systems are used to assess firms, monitor managers, facilitate risk management, and mobilise savings. This variable has two main components: finance activity, which is a measure of the overall activity of the financial intermediaries and markets, and finance size, which is a measure of the overall size of the financial sector. The expected sign of the coefficient of FINDEV is negative because a higher level of financial development implies that more information is available in the market to make decisions. This makes the earnings forecasts relatively less relevant to the market, and therefore the reaction to meeting (or failing to meet) forecasts is lower.

- Number of analysts following (AFOLL): This variable is defined as the number of analysts following companies in the market. We expect a positive relationship between AFOLL and the dependent variable. When there are more analysts following companies, the analysts' forecasts are more relevant and reliable for investors, and so the share price reaction to meeting or failing to meet earnings forecasts will be greater.

- Accuracy $(A C C)$ : When the accuracy of forecasts is higher, the market's surprise at deviations from forecasts is greater, causing a stronger market reaction. Given that we measure this variable as the deviation of actual earnings with respect to earnings forecasts, lower values indicate greater accuracy. Thus, it is expected that the sign of the coefficient of this variable will be negative.

- Logarithm of GDP per capita (lGDP): This variable measures the economic development of each country. The higher the GDP per capita, the more wealth is available to 
investors to make investments. In relative terms, the impact of positive news (compliance with forecasts) or negative news (non-compliance) will have a lower impact on wealthier investors, while investors with less wealth will be more sensitive to this news and the market reaction will be higher. Thus, we expect the sign for the coefficient of lGDP to be negative.

Finally, we test hypothesis $\mathrm{H}_{2}$ : the magnitude of the reward (penalty) offered by the market for meeting (not meeting) earnings forecasts influences the probability that a company will perceive an incentive to manage earnings.

To do so, we perform a logistic regression (equation 2) in which ITVE is the dependent variable, mean $|C A R|$ is the explanatory variable, and the other variables are control variables. The variables used to test $\mathrm{H}_{2}$ are defined in Annex 1 .

$$
\begin{aligned}
I T V E_{i t}= & \alpha_{0}+\alpha_{1} \text { mean }\left|C A R_{j t-1}\right|+\alpha_{2} L I Q_{i t}+\alpha_{3} S O L V_{i t} \\
& +\alpha_{4} D E B T_{i t}+\alpha_{5} R O I_{i t}++\alpha_{6} S I Z E_{i t} \\
& +\alpha_{7} \operatorname{varGDP}_{t}+\alpha_{8} \operatorname{rot} M K T_{j t}+e_{i t}
\end{aligned}
$$

where:

$I T V E_{i t}$ is the dependent variable, which represents the incentive of firm $i$ in period $t$ to manage earnings upward to meet earnings forecasts. Its value is 1 for firms with the incentive to manage earnings and 0 otherwise. Its computation is presented in Annex 2.

mean $\left|C A R_{j t-1}\right|$ is the explanatory variable, which quantifies the average reward (or penalty) in market $j$ in period $t-1$ for meeting (or failing to meet) earnings forecasts. It is defined as the mean absolute $C A R$ value in $\mathrm{a} \pm 1$ window around the earnings announcement date for firms listed in index $\mathrm{j}$ in period $\mathrm{t}-1$. Its computation is presented in Annex 2.

$L I Q_{i t}$ is the liquidity ratio for firm $i$ in period $t$, which we define as the quotient between current assets and current liabilities (data extracted from Datastream).

$S O L V_{i t}$ is the solvency ratio for firm $i$ in period $t$, which we define as the quotient between total assets and total liabilities (data extracted from Datastream).

$D E B T_{i t}$ is the debt ratio for firm $i$ in period $t$, which we define as the quotient between liabilities and equity (data extracted from Datastream).

$R O I_{i t}$ is the return on investment for firm $i$ in period $t$, which we define as the quotient between operating profits and total assets (data extracted from Datastream).

$S I Z E_{i t}$ measures the size of firm $i$ in period $t$, which we define using the asset logarithm (data extracted from Datastream).

$\operatorname{varGDP_{t}}$ is the percentage variation in GDP between year $t$ and $t-1$ in the country in which market $j$ is located (data obtained from World Bank)

$\operatorname{rot} M K T_{j t}$ is a proxy of the liquidity of market $j$ in period $t$, which we define as the quotient between trade volume and market capitalisation at the end of year $t$ (data extracted from Datastream)

Below, we explain the variables in the regression as well as the expected signs of the relationships between independent variables and the dependent one.

Dependent variable (ITVE): This variable identifies the incentive to upwardly manage earnings to meet earnings forecasts. It is a dichotomous variable whose value is 1 for firms that have the incentive to manage earnings upwards and they do so. The value is 0 for firms without the incentive to manage earnings upwards to meet forecasts because they met them without earnings management.

To assign a value of 1 or 0 to the variable, we have to know whether the company has managed earnings upward or not. In order to do so, we use discretionary accruals $(D A)$, which is the most common methodology in the literature for detecting earnings management (García Osma et al., 2005; McNichols, 2000). Accruals are defined as the part of earnings that does not involve cash flow and therefore are more likely to be manipulated by managers. However, not all accruals can be managed, so we can distinguish between non-discretionary accruals $(N D A)$, which are not manipulated by management since they depend on the economic circumstances of the company, and discretionary accruals, which are subject to the discretion of the management and therefore vulnerable to being managed $^{5}$.

Since it is possible to observe total accrual (TA), the nondiscretionary accruals (NDA) are estimated to subsequently calculate the discretionary component $(D A)$ as the difference between the total accruals and the estimated nondiscretionary accruals ${ }^{6}$. A positive value of $D A$ indicates upwards earnings management, and a negative one indicates downwards earnings management. We draw upon Dechow, Sloan, and Sweene (1995) model, as we explain in Annex 2. The descriptive statistics for $D A$ obtained from this model are shown in Table 4.

Table 4

Descriptive statistics for DA (discretionary accruals) from Dechow et al. (1995) model

$$
\frac{T A_{i t}}{A_{i t-1}}=\alpha_{1} \frac{1}{A_{i t-1}}+\alpha_{2} \frac{\Delta S A L E_{i t}-\Delta R E C_{i t}}{A_{i t-1}}+\alpha_{3} \frac{P P E_{i t}}{A_{i t-1}}+e_{i t}
$$

\begin{tabular}{lcccc}
\hline Variable & Minimum & Maximum & Mean & $\begin{array}{c}\text { Standard } \\
\text { deviation }\end{array}$ \\
\hline DA (BOVESPA) & -0.1624 & 0.1959 & 0.0053 & 0.0559 \\
DA (DAX) & -0.0932 & 0.0952 & 0.0005 & 0.0287 \\
DA (DOW JONES) & -0.0684 & 0.0609 & 0.0012 & 0.0206 \\
DA (FTSE) & -0.1166 & 0.1168 & 0.0005 & 0.0348 \\
DA (HANG SENG) & -0.1384 & 0.1369 & -0.0019 & 0.0424 \\
DA (IBEX) & -0.0953 & 0.1012 & 0.0045 & 0.0304 \\
\hline
\end{tabular}

DA (INDEX): Discretionary accruals obtained from the estimation of Dechow et al. (1995) model for the firms listed in each INDEX

$$
\frac{D A_{i t}}{A_{i t-1}}=\frac{T A_{i t}}{A_{i t-1}}-\left(a_{1} \frac{1}{A_{i t-1}}+a_{2} \frac{\left(\Delta S A L E_{i t}-\Delta R E C_{i t}\right)}{A_{i t-1}}+a_{3} \frac{P P E_{i t}}{A_{i t-1}}\right)
$$

$D A_{i t}$ is the discretionary accruals for firm $\mathrm{i}$ in period $\mathrm{t}$ and

$a_{1}, a_{2}$ and $a_{3}$ are the estimated values of parameters $\alpha_{1}$ to $\alpha_{3}$

$T A_{i t}$ is the total accruals for firm $\mathrm{i}$ in period $\mathrm{t}$, which has been calculated using the difference between actual earnings (AE) and cash flow from operations (CFO): $T A_{i t}=A E_{i t}-C F O_{i t}$

$\triangle S A L E_{i t}$ is the change in sales for firm i in period t compared with $\mathrm{t}-1$. $\triangle R E C_{i t}$ is the change in receivables for firm $\mathrm{i}$ in period $\mathrm{t}$ compared with $\mathrm{t}-1$. $P P E_{i t}$ is property, plant and equipment for firm $\mathrm{i}$ in period $\mathrm{t}$.

$A_{i t-1}$ is the total assets figure for firm i in period $\mathrm{t}-1$ and we have used it as a deflator to prevent heteroscedasticity problems

Data are extracted from DATASTREAM

The firms that met their earnings forecasts may (or not) have perceived an incentive to manage earnings in order

${ }^{5}$ The concepts of discretionary and non-discretionary accruals are explained by Dechow et al. (2010), Francis et al. (2004) and Kothari et al. (2005), among others.

${ }^{6}$ Different models have been used in the literature to estimate nondiscretionary accruals. A comprehensive overview of these models is presented by Callao et al. (2014). 
to meet these forecasts. Consequently, the value of ITVE is 1 for firms who meet earnings forecasts when their nondiscretionary earnings $(N D E)$ are below the earnings forecast $(E F)$ and their discretionary accruals $(D A)$ are positive $(N D E<E F$ and $D A>0)$ That is, this value is assigned when firms have an incentive to manage earnings upwards to reach forecasts and do so. The value of ITVE is 0 for firms who meet earnings forecasts when their non-discretionary earnings are above the earnings forecast $(N D E>E F)$. In these cases, firms lack an incentive to manage earnings upwards to meet earnings forecasts (note that earnings may be managed, but the incentive for doing so is not to meet earnings forecasts). The process used to assign values of 1 or 0 to ITVE is explained in Annex 1.

Explanatory variable (mean $|C A R|$ ): As indicated above, this variable is defined as the mean of the absolute values of the cumulative abnormal return of the shares listed in a certain market in $\mathrm{a} \pm 1$ window around earnings announcement date, which is when we know whether companies met their earnings forecasts. We introduce the reward (or penalty) with a delay period, because the manager's incentive to meet analysts' forecasts will depend on the reaction of the market in the past $(t-1)$. The variable is calculated for each studied year according to the process explained in Annex 2.

The statistical significance of the mean $\left|C A R_{j t-1}\right|$ variable indicates that the cumulative abnormal return around the earnings announcement date, as a measure of the reward (or penalty) the firm receives for meeting (or failing to meet) earnings forecasts, is related to a firm's motivation to manage its earnings to meet these forecasts. The expected coefficient sign is positive since the greater the reward (penalty) for meeting (failing to meet) forecasts, the more likely the firm will perceive an incentive to manage earnings.

Control variables: We introduce seven control variables in the model:

- Economic-financial ratios measuring the liquidity (LIQ), solvency $(S O L V)$, indebtedness (DEBT) and return on investment $(R O I)$ of the firms: Since the economic and financial position of firms influences their earnings management (Bikky \& Picheng, 2002; Charitou et al., 2012; DeFond \& Jiambalvo, 1994; Iatridis \& Kadorinis, 2009; Rosner, 2003; Sweeney, 1994), we expect that a worse economic and financial situation (lower liquidity, solvency and profitability and higher indebtedness) will be associated with greater incentives to manage earnings. So, the expected sign for $L I Q, S O L V$ and ROI is negative and that for DEBT is positive.

- Firm size (SIZE): Many prior studies have analysed the relationship between firm size and earnings management, proposing diverse conclusions (e.g. Barton \& Simko, 2002; Burgstahler \& Dichev, 1997; Kim et al., 2003; Llukani, 2013; Swastika, 2013). In our case, we have to consider that larger companies are more visible in the market and are usually followed by more analysts. This may increase companies' fear of not meeting forecasts and thus increase the probability that they will manage earnings. Hence, the expected sign is positive.

- Variation of GDP (varGDP): Through this variable, we control for the effect of changes in economic situation on the incentive to manage earnings. We expect to find a negative relationship, indicating that good evolution of GDP may limit the incentive to manage earnings (Chih, Shen, \& Kang, 2007, and Shen \& Chih, 2005, point out that those richer countries are generally less likely to manage earnings).
- Market liquidity ( $\operatorname{rot} M K T)$ : This variable represents the degree of ease or difficulty of finding a counterpart, buyer or seller for a share. Ascioglu, Hegde, Krishnan, and McDermott (2012) suggest that firms exhibiting greater earnings management are associated with lower market liquidity. However, Huang, Lao, and McPhee (2017) show that stock liquidity increases accrual-based earnings management. Thus, we cannot predict the sign of the relationship between $\operatorname{rot} M K T$ and the incentive to manage earnings.

The descriptive statistics for the variables in regression (2) are presented in Table 5, and the correlations between these variables are shown in Table 6 . As can be seen, the correlations between the variables are low or moderate and the signs of the correlations are as expected. The negative sign of the correlation between mean $|C A R|$ and $v a r G D P$ may be surprising. This indicates that when the economy gets worse, the reward (penalty) for companies that meet (fail to meet) their earnings forecasts is higher. Investors think that when the economy is improving, companies are able to meet earnings forecasts more easily. We must consider that CAR is measured in $\mathrm{a} \pm 1$ window around the earnings announcement. Thus, CAR does not measure the evolution of stock prices, but the reaction to a particular event within a short period. The negative relationship between $\operatorname{varGDP}$ and $\operatorname{rot} M K T$ may also draw attention apriori, but this is not surprising if we consider that $\operatorname{rot} M K T$ is the quotient between trade volume and market capitalisation. In rising periods, both trade volume and capitalisation can increase, but if capitalisation increases proportionally more than trade volume (because, for example, investments are more stable), the quotient will decrease. In the other hand, in rising periods not always the volume trade increases because sometimes the investments are more stable.

Table 5

Descriptive statistics for variables in equation 2

Variable Minimum Maximum Mean Standard deviation

\begin{tabular}{lcccc}
\hline Mean | CAR & 0.01 & 0.04 & 0.02 & 0.005 \\
LIQ & 0.00 & 6.87 & 1.38 & 0.75 \\
SOLV & 0.47 & 9.83 & 1.89 & 0.83 \\
DEBT & 0.10 & 13.8 & 2.03 & 2.15 \\
ROI & -0.16 & 0.39 & 0.09 & 0.06 \\
SIZE & 5.39 & 9.77 & 7.31 & 0.70 \\
varGDP & -5.61 & 14.23 & 2.35 & 3.65 \\
rotMKT & 12.37 & 248.57 & 70.21 & 60.37 \\
\hline
\end{tabular}

mean $\left|C A R_{j t-1}\right|$ is the explanatory variable quantifying the average reward (or penalty) in market $\mathrm{j}$ in period $\mathrm{t}-1$ for meeting (or failing) to meet earnings forecasts. It is defined as the mean of the absolute values of cumulative abnormal return in a $-1+1$ window around the earnings announcement date for firms listed in index $\mathrm{j}$ in period t-1. See computation in Annex 2 .

$L I Q_{i t}$ is the liquidity ratio for firm $\mathrm{i}$ in period $\mathrm{t}$, which we define as the quotient between the current assets and current liabilities (data from DATASTREAM).

$S O L V_{i t}$ is the solvency ratio for firm i in period $\mathrm{t}$, which we define as the quotient between the total assets and total liabilities (data from DATASTREAM).

$D E B T_{i t}$ is the debt ratio for firm $\mathrm{i}$ in period $\mathrm{t}$, which we define as the quotient between the liabilities and equity (data from DATASTREAM).

$R O I_{i t}$ is the return-on-investment for firm $\mathrm{i}$ in period $\mathrm{t}$, which we define as the quotient between the operating profits and total assets (data from DATASTREAM).

$S I Z E_{\text {it }}$ measures the size of firm $\mathrm{i}$ in period $\mathrm{t}$, and we define it using the asset logarithm (data from DATASTREAM)

$\operatorname{varGDP} P_{j t}$ is the percentage variation of Gross Domestic Product (GDP) between year $\mathrm{t}$ and $\mathrm{t}-1$ in the country in which market $\mathrm{j}$ is located (data from Worl Bank)

$\operatorname{rot} M K T_{j t}$ is a proxy of the liquidity of market $\mathrm{j}$ in period $\mathrm{t}$, which is defined as the quotient between the trade volume and the market capitalization at the end of year $\mathrm{t}$ (data from DATASTREAM). 
Table 6

Pearson Correlations (variables in equation 2)

\begin{tabular}{lrrrrrrr}
\hline & mean & CAR $~$ & LIQ & SOLV & DEBT & ROI & SIZE varGDP rotMKT \\
\hline mean | CAR | & 1 & & & & & & \\
LIQ & $-0.058^{*}$ & 1 & & & & & \\
SOLV & $-0.084^{* *}$ & $0.471^{* *}$ & 1 & & & & \\
DEBT & 0.036 & $-0.178^{* *}$ & $-0.332^{* *}$ & 1 & & & \\
ROI & 0.037 & $0.153^{* *}$ & $0.200^{* *}$ & $-0.135^{* *}$ & 1 & & 1 \\
SIZE & $-0.331^{* *}$ & $-0.149^{* *}$ & 0.028 & -0.003 & $-0.131^{* *}$ & 1 & 1 \\
varGDP & $-0.313^{* *}$ & $0.075^{* *}$ & $0.251^{* *}$ & $-0.133^{* *}$ & 0.037 & $0.274^{* *}$ & 1 \\
rotMKT & $0.411^{* *}$ & $-0.085^{* *}$ & -0.043 & 0.038 & $0.079^{* *}$ & $-0.368^{* *}-0.324^{* *}$ & 1 \\
\hline
\end{tabular}

* Significant at 0.05

* Significant at 0.01

mean $\left|C A R_{j t-1}\right|$ is the explanatory variable quantifying the average reward (or penalty) in market $\mathrm{j}$ in period $\mathrm{t}-1$ for meeting (or failing) to meet earnings forecasts. It is defined as the mean of the absolute values of cumulative abnormal return in a $-1+1$ window around the earnings announcement date for firms listed in index $\mathrm{j}$ in period t-1. See computation in Annex 2.

$L I Q_{i t}$ is the liquidity ratio for firm i in period $\mathrm{t}$, which we define as the quotient between the current assets and current liabilities (data from DATASTREAM).

$S O L V_{i t}$ is the solvency ratio for firm i in period t, which we define as the quotient between the total assets and total liabilities (data from DATASTREAM).

$D E B T_{i t}$ is the debt ratio for firm i in period $t$, which we define as the quotient between the liabilities and equity (data from DATASTREAM)

$R O I_{i t}$ is the return-on-investment for firm i in period $t$, which we define as the quotient between the operating profits and total assets (data from DATASTREAM).

$S I Z E_{i t}$ measures the size of firm $\mathrm{i}$ in period $\mathrm{t}$, and we define it using the asset logarithm (data from DATASTREAM).

$\operatorname{varGDP} P_{j t}$ is the percentage variation of Gross Domestic Product (GDP) between year $\mathrm{t}$ and $\mathrm{t}-1$ in the country in which market $\mathrm{j}$ is located (data from World Bank)

$\operatorname{rot} M K T_{i t}$ is a proxy of the liquidity of market $\mathrm{j}$ in period $\mathrm{t}$, which is defined as the quotient between the trade volume and the market capitalization at the end of year $\mathrm{t}$ (data from DATASTREAM).

\section{Results}

This paper investigates whether the reward (penalty) for meeting (failing to meet) analysts' forecasts differs between markets $\left(\mathrm{H}_{1}\right)$ and whether the market's reaction influences the incentive for companies to manage earnings to meet forecasts $\left(\mathrm{H}_{2}\right)$.

We find significant differences in the reward (penalty) for meeting (failing to meet) earnings forecasts between the markets. The results of the non-parametric Kruskal-Wallis test of $\mathrm{k}$ independent samples (Table 7) highlight significant differences in mean $|C A R|$ across the six indices we analysed. In other words, we can confirm that the reaction of share prices to meeting (or failing to meet) an earnings forecast is significantly different at the $1 \%$ level. Previous studies have already investigated the market's reaction when it is known whether companies reached their earnings forecasts or not (Bartov et al., 2002; Edmonds et al., 2018; Kasznik \& McNichols, 2002; Kinney et al., 2002; López \& Rees, 2002; Skinner \& Sloan, 2002). However, these studies focused only on one market, most often the US market, so we cannot compare our results with theirs. However, we can affirm that the results coincide with our expectations, since changes in share prices, which determine $C A R$, depend on many factors that differ between the markets we study.

The ranks generated by the Kruskal-Wallis test (Table 8) show that meeting (or failing to meet) forecasts has the most impact on $C A R$ in the British market, followed by the German, American, Brazilian, Spanish and Hong Kong markets. In other words, the reaction of share prices to earnings announcements, which provide information about whether analysts' forecasts were met or not, is strongest in the British and German markets and weakest in the Spanish and Hong Kong markets. Furthermore, the results of the Mann-Whitney test, which was conducted to compare the reaction for each pair of markets (Table 9), indicate that, in general, each market
Table 7

Kruskal-Wallis test results

\begin{tabular}{lc}
\hline & mean | CAR | \\
\hline Chi-squared & 1423.991 \\
df & 5 \\
Asymptotic sig. & .000 \\
\hline
\end{tabular}

mean $|C A R|$ is defined as the mean of the absolute values of cumulative abnormal return in a $-1+1$ window around the earnings announcement date for firms listed in the indexes under study. It measures the reward (or penalty) for meeting (or failing) to meet earnings forecasts. See computation in Annex 2.

Table 8

Kruskal-Wallis test ranks

\begin{tabular}{cccc}
\hline & INDEX & N & Average rank \\
\hline mean | CAR | & BOVESPA & 440 & 646.83 \\
& DAX & 240 & 1330.06 \\
& DOW JONES & 250 & 626.78 \\
& FTSE & 770 & 1602.44 \\
HANG-SENG & 280 & 470.50 \\
IBEX & 260 & 511.17 \\
Total & $\mathbf{2 , 2 4 0}$ & \\
\hline
\end{tabular}

mean $|C A R|$ is defined as the mean of the absolute values of cumulative abnormal return in a $-1+1$ window around the earnings announcement date for firms listed in the indexes under study. It measures the reward (or penalty) for meeting (or failing) to meet earnings forecasts. See computation in Annex 2.

Table 9

Mann-Whitney test results

\begin{tabular}{lrrrrl}
\hline mean | CAR | & DAX & DOW JONES & \multicolumn{1}{c}{ FTSE } & HANG SENG & \multicolumn{1}{l}{ IBEX } \\
\hline Mann-Whitney U & 0.000 & 35200 & 0.000 & 34496 & 34320 BOVESA \\
Wilcoxon W & 78606 & 60625 & 78606 & 66374 & 61815 \\
Z & -20.500 & -4.359 & -27.535 & -6.641 & -5.452 \\
Asymptotic sig. & 0.000 & 0.000 & 0.000 & 0.000 & 0.000 \\
Mann-Whitney U & & 4800 & 34416 & 0.000 & 1872 DAX \\
Wilcoxon W & & 30225 & 54852 & 31878 & 29367 \\
Z & -14.597 & -12.926 & -18.689 & -17.004 \\
Asymptotic sig. & 0.000 & 0.000 & 0.000 & 0.000 \\
Mann-Whitney U & & 15400 & 23800 & 25350 DOW \\
Wilcoxon W & & 40825 & 55678 & 52845 JONES \\
Z & & -18.155 & -3.032 & -0.687 \\
Asymptotic sig. & & 0.000 & 0.002 & 0.492 \\
Mann-Whitney U & & & 0.000 & 0.000 FTSE \\
Wilcoxon W & & & 31878 & 27495 \\
Z & & & -23.594 & -22.958 \\
Asymptotic sig. & & & 0.000 & 0.000 \\
Mann-Whitney U & & & & 283920 HANG \\
Wilcoxon W & & & & 60270 SENG \\
Z & & & & 0.707 \\
Asymptotic sig. & & & & & \\
\hline
\end{tabular}

mean $|C A R|$ is defined as the mean of the absolute values of cumulative abnormal return in a - $1+1$ window around the earnings announcement date for firms listed in the indexes under study. It measures the reward (or penalty) for meeting (or failing) to meet earnings forecasts. See computation in Annex 2.

reacts in a significantly different way to the other markets.

To identify which characteristics of the markets and countries may explain differences in market reactions, we performed regression (1). The results are shown in Table 10.

The table shows that all the variables are significant at the $1 \%$ level, except ACC, which is significant at $10 \%$. The positive sign of the coefficient of $L E G$ indicates that the reaction of a company's share prices to meeting or failing to meet an earnings forecast is higher in stock markets in countries with a Roman Germanic legal tradition (i.e. a code law system). The fact that these countries have less of a stock market tradition than those based on Anglo-Saxon legal traditions 
Table 10

Linear regression results (equation 1)

mean $\left|C A R_{j t}\right|=\alpha_{0}+\alpha_{1} L E G_{j}+\alpha_{2} F I N D E V_{j}+\alpha_{3} A F O L L_{i t}+\alpha_{4} A C C_{i t}+\alpha_{5} l G D P_{j t}+e_{i t}$

\begin{tabular}{lccl}
\hline & $\mathrm{B}$ & Standard error & Sig. \\
\hline LEG & 0.014 & 0.001 & 0.000 \\
FINDEV & -0.020 & 0.002 & 0.000 \\
AFOLL & 0.000 & 0.000 & 0.000 \\
ACC & -0.369 & 0.011 & 0.084 \\
lGDP & -0.133 & 0.010 & 0.000 \\
Constant & 0.679 & 0.046 & 0.419 \\
\hline
\end{tabular}

mean $\left|C A R_{j t}\right|$ is the dependent variable and quantifying the average reward (or penalty) in market $\mathrm{j}$ in period $\mathrm{t}$ for meeting (or failing) to meet earnings forecasts. It is defined as the mean of the absolute values of cumulative abnormal return in a $-1+1$ window around the earnings announcement date for firms listed in index $\mathrm{j}$ in period t. See computation in Annex 2.

$L E G_{j}$ is a dichotomous variable representing the legal system of country $\mathrm{j}$, taking value 0 for common law and value 1 for code law, according to the classification by Djankov et al. (2007).

FINDEV $V_{j}$ measures the level of financial development for country $\mathrm{j}$ by the variable Finance-Aggregate taken from Beck and Levine, (2002).

$A F O L L_{i t}$ is the number of analysts following the company $\mathrm{i}$ in period $\mathrm{t}$ (data extracted from $\mathrm{I} / \mathrm{B} / \mathrm{E} / \mathrm{S})$.

$A C C_{i t}$ is the absolute difference between actual earnings and earnings forecast scaled by earnings forecast for company $i$ in period $t$ (actual data extracted from DATASTREAM and forecasted data extracted from $\mathrm{I} / \mathrm{B} / \mathrm{E} / \mathrm{S}$ )

$l G D P_{j t}$ is the logarithm of GDP per capita for country $\mathrm{j}$ in period $\mathrm{t}$ (data from Word Bank)

(i.e. those with a common law system) may explain this relationship. Analysts' forecasts can be considered a more relevant source of information in countries with a code law system, where there are not as many sophisticated analytical elements as in more developed markets. Thus, the market will have a stronger reaction to meeting or failing to meet earnings forecasts will be stronger.

As expected, there is a negative relationship between FINDEV and the market's reaction. The higher level of information available in more developed markets means that analysts' forecasts are not as important for investors' decisionmaking. For this reason, the impact of meeting earnings forecasts on the cumulative abnormal return of shares will not be as significant as in the markets with less availability of information.

AFOLL has a positive relationship with the dependent variable. A greater number of analysts following a company implies that the company is more visible to the market. This leads investors to have a greater reaction to companies that meet or fail to meet earnings forecasts.

As expected, the coefficient of $A C C$ is negative. In markets in which forecasts are more accurate and there is lower earnings deviation from forecasts (i.e. lower $A C C$ values), investors are accustomed to companies meeting earnings forecasts. Failure to meet these forecasts will be received with surprise by these markets, and they will react more strongly than markets more accustomed to less accurate earnings forecasts.

Finally, the market reaction is greater in countries with lower GDP per capita, as investors have fewer available resources to make investments and the lower return on their investments has a greater impact on their wealth. Thus, meeting (failing to meet) earnings forecasts, which is considered positive (negative) news by investors, will generate a greater reward (penalty) within the market.

After establishing that there are significant differences in the way markets behave, we focused on assessing whether the impact of meeting (or failing to meet) forecasts influences firms' perceived incentive to meet their forecasts through earnings management.

We conducted a logistic regression (equation 2) for that purpose, the results of which are shown in Table 11 . The model correctly classified $61.7 \%$ of cases.

Table 11

Logistic regression results (equation 2)

$I T V E_{i t}=\alpha_{0}+\alpha_{1}$ mean $\left|C A R_{j t-1}\right|+\alpha_{2} L I Q_{i t}+\alpha_{3} S O L V_{i t}+\alpha_{4} D E B T_{i t}+\alpha_{5} R O I_{i t}$ $+\alpha_{6} S I Z E_{i t}+\alpha_{7} \operatorname{varGDP} P_{j t}+\alpha_{8} \operatorname{rot} M K T_{j t}+e_{i t}$

\begin{tabular}{lrccrc}
\hline & \multicolumn{1}{c}{ B } & Standard error & Wald & df & Sig. \\
\hline mean | CAR $-1 \mid$ & 47.868 & 19.345 & 6.123 & 1 & 0.013 \\
LIQ & 0.072 & 0.158 & 0.209 & 1 & 0.648 \\
SOLV & 0.113 & 0.195 & 0.333 & 1 & 0.564 \\
DEBT & -0.121 & 0.075 & 2.574 & 1 & 0.109 \\
ROI & 3.118 & 1.546 & 4.064 & 1 & 0.044 \\
SIZE & 0.015 & 0.171 & 0.008 & 1 & 0.930 \\
varGDP & -0.054 & 0.026 & 4.195 & 1 & 0.041 \\
rotMKT & -0.008 & 0.004 & 3.088 & 1 & 0.079 \\
Constant & -1.146 & 1.430 & 0.642 & 1 & 0.423 \\
\hline
\end{tabular}

$I T V E_{i t}$ is the dependent variable representing the incentive of firm i in period to manage earnings upward to meet analysts forecasts. Its value will be 1 for firms with the incentive to manage earnings and 0 otherwise. See computation in Annex 2.

mean $\left|C A R_{j t-1}\right|$ is the explanatory variable quantifying the average reward (or penalty) in market $\mathrm{j}$ in period $\mathrm{t}-1$ for meeting (or failing) to meet earnings forecasts. It is defined as the mean of the absolute values of cumulative abnormal return in a $-1+1$ window around the earnings announcement date for firms listed in index $j$ in period t-1. See computation in Annex 2.

$L I Q_{i t}$ is the liquidity ratio for firm i in period $\mathrm{t}$, which we define as the quotient between the current assets and current liabilities (data from DATASTREAM).

$S O L V_{i t}$ is the solvency ratio for firm i in period $\mathrm{t}$, which we define as the quotient between the total assets and total liabilities (data from DATASTREAM).

$D E B T_{i t}$ is the debt ratio for firm $\mathrm{i}$ in period $\mathrm{t}$, which we define as the quotient between the liabilities and equity (data from DATASTREAM).

$R O I_{i t}$ is the return-on-investment for firm $\mathrm{i}$ in period $\mathrm{t}$, which we define as the quotient between the operating profits and total assets (data from DATASTREAM).

$S I Z E_{i t}$ measures the size of firm $\mathrm{i}$ in period $\mathrm{t}$, and we define it using the asset logarithm (data from DATASTREAM).

$\operatorname{varGDP} P_{j t}$ is the percentage variation of Gross Domestic Product (GDP) between year $\mathrm{t}$ and $\mathrm{t}-1$ in the country in which market $\mathrm{j}$ is located (data from World Bank).

$\operatorname{rot} M K T_{j t}$ is a proxy of the liquidity of market $\mathrm{j}$ in period $\mathrm{t}$, which is defined as the quotient between the trade volume and the market capitalization at the end of year $\mathrm{t}$ (data from DATASTREAM).

The relevant variable for the proposed objective is mean $|C A R|$. As we can observe, it is significant at the $5 \%$ level; in other words, the impact of meeting earnings forecasts on the cumulative abnormal return of shares explains firms' incentive to manage earnings to meet analysts' forecasts. As mentioned above, previous studies (Bartov et al., 2002; Edmonds et al., 2018; Skinner \& Sloan, 2002) have examined the positive (negative) market reaction when companies meet (fail to meet) earnings forecasts (i.e. the $C A R$ around an earnings announcement). Likewise, previous studies (e.g. Callao \& Jarne, 2018; Dechow et al., 2000; Matsumoto, 2002; Payne \& Robb, 2000) have proven that there is a relationship between earnings management and earnings forecasts, and other investigations (Caneghem, 2002; García Osma et al., 2005; Niskanen \& Keloharju, 2000) identified analysts' forecasts as possible incentives for earnings management.

The present paper provides evidence that the relationship between earnings management and meeting earnings forecasts (ITVE) depends on the magnitude of the market reaction when companies meet (or fail to meet) earnings forecasts (CAR around earnings announcements). Since we find significant differences in the magnitude of the market reaction, the results suggest that the incentive to manage earnings in order to meet forecasts depends on the market in 
which a company is listed.

The positive variable coefficient means that the larger the market's reward (penalty) for meeting (failing to meet) analysts' forecasts, the more likely it is that companies will perceive an incentive to manage earnings. This is the case for firms listed in the FTSE and DAX indexes. The firms listed in the Hang Seng and IBEX indexes are those that perceive this incentive to be least strong.

$R O I$ is the only financial variable that is significant (at the $5 \%$ level). This suggests that analysts are more demanding with the most profitable companies when they forecast their earnings and therefore these firms are more likely to manipulate their accounting figures to attain these high-return targets. The other financial ratios are not significant, which means that the company's financial position is not very relevant to earnings management performed to meet earnings forecasts, unlike when companies manage earnings for other reasons.

Two other control variables are significant: $\operatorname{varGDP}$ (at the $5 \%$ level) and rotMKT (at the 10\% level). Our expectation for varGDP, which was based on the work of Chih et al. (2007) and Shen and Chih (2005), was met. The negative coefficient indicates that the more the GDP decreases and the economy worsens, the greater the likelihood that companies will perceive an incentive to manage earnings in order to meet forecasts. A negative coefficient was also found for $\operatorname{rotMKT}$, which indicates that when the market is more liquid, there is a lower probability that companies will perceive an incentive to manage earnings. Since some studies suggest a positive relationship in this regard and others suggest the opposite, we did not predicted the sign of the coefficient. However, our results align with those of Ascioglu et al. (2012).

\section{Sensitivity analysis}

The results of our study could be biased by the model used to obtain $D A$, the value of which was used to determine the value of the dependent variable, ITVE, in regression (2). For this reason, we carried out a sensitivity analysis, repeating our study using Larcker and Richardson's (2004) model and equation (3) to estimate accruals:

$$
\begin{aligned}
\frac{T A_{i t}}{A_{i t-1}}= & \alpha_{1} \frac{1}{A_{i t-1}}+\alpha_{2} \frac{\left(\Delta S A L E_{i t}-\Delta R E C_{i t}\right)}{A_{i t-1}}+\alpha_{3} \frac{P P E_{i t}}{A_{i t-1}} \\
& +\alpha_{4} B t M_{i t}+\alpha_{5} \frac{C F O_{i t}}{A_{i t-1}}+e_{i t}
\end{aligned}
$$

where:

$T A_{i t}$ represents the total accruals for firm *i* in period $* t *$, which were calculated based on the difference between actual earnings (AE) and cash flow from operations (CFO): $* \mathrm{TA}$ it $=* \mathrm{AE}^{*}$ it * $-\mathrm{CFO} *$ it *.

$\triangle S A L E_{i t}$ represents the change in sales for firm * $\mathrm{i} *$ in period $* t *$ compared to *t*-1.

$\triangle R E C_{i t}$ represents the change in receivables for firm *i* in period *t* compared to * $\mathrm{t} *-1$.

$P P E_{i t}$ represents the property, plants and equipment of firm $* i *$ in period * $t *$.

$B t M_{i t}$ represents the book to market ratio for firm *i* in period *t*.

$\mathrm{CFO}_{i t}$ represents the cash flow from operations for firm * $\mathrm{i}$ * in period * $t *$.
$A_{i t-1}$ represents the total assets of firm $* \mathrm{i} *$ in period $* t *-1$, which we used as a deflator to prevent heteroscedasticity problems.

$e_{i t}$ is the error term for firm *i* in period *t*.

For this regression, data were extracted from Datastream.

After estimating the parameters for equation (3), we used these values to predict the total accruals during the period of analysis (2006-2015) and to calculate the prediction error using equation (4):

$$
\begin{aligned}
\frac{D A_{i t}}{A_{i t-1}}=\frac{T A_{i t}}{A_{i t-1}}-( & a_{1} \frac{1}{A_{i t-1}}+a_{2} \frac{\left(\Delta S A L E_{i t}-\Delta R E C_{i t}\right)}{A_{i t-1}} \\
& \left.+a_{3} \frac{P P E_{i t}}{A_{i t-1}}+a_{4} B t M_{i t}+a_{5} \frac{C F O_{i t}}{A_{i t-1}}\right)
\end{aligned}
$$

where $D A_{i t}$ represents the discretionary accruals for firm $i$ in period $t$ and $a_{1}, a_{2}, a_{3}, a_{4}$ and $a_{5}$ are the estimated values of parameters $\alpha_{1}-\alpha_{5}$.

The descriptive statistics for $D A$, which were estimated based on Larcker and Richardson's (2004) model, are presented in Table 12.

\section{Table 12}

Descriptive statistics for DA (discretionary accruals) from Larcker \& Richardson (2004) model

$$
\frac{T A_{i t}}{A_{i t-1}}=\alpha_{1} \frac{1}{A_{i t-1}}+\alpha_{2} \frac{\left(\Delta S A L E_{i t}-\Delta R E C_{i t}\right)}{A_{i t-1}}+\alpha_{3} \frac{P P E_{i t}}{A_{i t-1}}+\alpha_{4} B t M_{i t}+\alpha_{5} \frac{C F O_{i t}}{A_{i t-1}}+e_{i t}
$$

\begin{tabular}{lcccc}
\hline Variable & Minimum & Maximum & Mean & Standard deviation \\
\hline DA (BOVESPA) & -0.1457 & 0.0138 & 0.0011 & 0.0451 \\
DA (DAX) & -0.0853 & 0.0853 & 0.0005 & 0.0262 \\
DA (DOW JONES) & -0.0632 & 0.0581 & 0.0011 & 0.0187 \\
DA (FTSE) & -0.1058 & 0.1009 & 0.0003 & 0.0309 \\
DA (HANG SENG) & -0.0978 & 0.1158 & -0.0021 & 0.0334 \\
DA (IBEX) & -0.0852 & 0.0788 & -0.0003 & 0.0246 \\
\hline
\end{tabular}

DA (INDEX): Discretionary accruals obtained from the estimation of Larcker and Richardson (2004) model for the firms listed in each INDEX

$\frac{D A_{i t}}{A_{i t-1}}=\frac{T A_{i t}}{A_{i t-1}}-\left(a_{1} \frac{1}{A_{i t-1}}+a_{2} \frac{\left(\Delta S A L E_{i t}-\Delta R E C_{i t}\right)}{A_{i t-1}}+a_{3} \frac{P P E_{i t}}{A_{i t-1}}+a_{4} B t M_{i t}+a_{5} \frac{C F O_{i t}}{A_{i t-1}}\right)$

$D A_{i t}$ is the discretionary accruals for firm $\mathrm{i}$ in period $\mathrm{t}$

$a_{1}, a_{2}, a_{3}, a_{4}$ and $a_{5}$ are the estimated values of parameters $\alpha_{1}$ to $\alpha_{5}$.

$T A_{i t}$ is the total accruals for firm $\mathrm{i}$ in period $\mathrm{t}$, which has been calculated using the difference between actual earnings (AE) and cash flow from operations (CFO):

$T A_{i t}=A E_{i t}-C F O_{i t}$

$S A L E_{i t}$ is the change in sales for firm i in period t compared with $\mathrm{t}-1$.

$R E C_{i t}$ is the change in receivables for firm $\mathrm{i}$ in period $\mathrm{t}$ compared with $\mathrm{t}-1$.

$P P E_{i t}$ is property, plant and equipment for firm $\mathrm{i}$ in period $\mathrm{t}$.

$B t M_{i t}$ is the book to market ratio for firm $\mathrm{i}$ in period $\mathrm{t}$.

$\mathrm{CFO}_{i t}$ is the cash flow from operations for firm $\mathrm{i}$ in period $\mathrm{t}$.

Taking into account the definition of ITVE, we allocated values of 1 and 0 depending on the estimations obtained with Larcker and Richardson's (2004) model. A value of 1 was assigned to firms for which $N D E_{i t}<E F_{i t}$ and $D A_{i t}>0$, and a value of 0 was assigned otherwise. Using the new values of ITVE variable (ITVE ${ }_{i t}$ ) obtained with Larcker and Richardson's (2004) model, we performed regression (2) again and obtained the results presented in Table 13.

As shown in the table, the results are not very different from those presented in Section 5, although the model correctly classifies only $59.5 \%$ of the cases, which is lower than the $61.7 \%$ correctly identified using the other model. As above, the explanatory variable, mean $|C A R|$, was significant at the $5 \%$ level and the coefficient had the expected sign.

With respect to the control variables, $R O I$ and $\operatorname{varGDP}$ were significant at the $10 \%$ level and had positive and negative 
signs, respectively. These results can be interpreted in the same way as those presented in Section 5. However, the liquidity of the market was insignificant.

Table 13

Logistic regression results (equation 2; Larcker \& Richardson, 2004) $I T V E_{i t}($ Larcker \& Richardson $)=\alpha_{0}+\alpha_{1}$ mean $\left|C A R_{j t-1}\right|+\alpha_{2} L I Q_{i t}+\alpha_{3} \operatorname{SOLV}_{i t}$ $+\alpha_{4} D E B T_{i t}+\alpha_{5} R O I_{i t}+\alpha_{6} S I Z E_{i t}+\alpha_{7} \operatorname{varGDP}_{t}+\alpha_{8} \operatorname{rot} \mathrm{MKT} T_{j t}+e_{i t}$

\begin{tabular}{lrcccc}
\hline & \multicolumn{1}{c}{ B } & Standard error & Wald & df & Sig. \\
\hline Mean $\mid$ CAR $_{\mathrm{t}-1} \mid$ & 46.532 & 19.258 & 5.838 & 1 & 0.016 \\
LIQ & 0.058 & 0.157 & 0.136 & 1 & 0.712 \\
SOLV & 0.125 & 0.195 & 0.412 & 1 & 0.521 \\
DEBT & -0.096 & 0.073 & 1.726 & 1 & 0.189 \\
'ROI & 2.945 & 1.541 & 3.653 & 1 & 0.056 \\
SIZE & 0.002 & 0.170 & 0.000 & 1 & 0.991 \\
varGDP & -0.046 & 0.026 & 3.092 & 1 & 0.079 \\
rotMKT & -0.006 & 0.004 & 1.642 & 1 & 0.200 \\
Constant & -1.151 & 1.424 & 0.654 & 1 & 0.419 \\
\hline
\end{tabular}

$I T V E_{i t}($ Larcker \& Richardson) is the dependent variable representing the incentive of firm $i$ in period t to manage earnings upward to meet analysts forecasts. Its value will be 1 for firms with the incentive to manage earnings and 0 otherwise. The allocation of these values is based on discretionary accruals estimated with Larcker and Richardson (2004) model.

mean $\left|C A R_{j t-1}\right|$ is the explanatory variable quantifying the average reward (or penalty) in market $\mathrm{j}$ in period $\mathrm{t}-1$ for meeting (or failing) to meet earnings forecasts. It is defined as the mean of the absolute values of cumulative abnormal return in a $-1+1$ window around the earnings announcement date for firms listed in index $\mathrm{j}$ in period $\mathrm{t}-1$.

$L I Q_{i t}$ is the liquidity ratio for firm i in period $\mathrm{t}$, which we define as the quotient between the current assets and current liabilities (data from DATASTREAM).

$S O L V_{i t}$ is the solvency ratio for firm i in period $\mathrm{t}$, which we define as the quotient between the total assets and total liabilities (data from DATASTREAM).

$D E B T_{i t}$ is the debt ratio for firm $\mathrm{i}$ in period $\mathrm{t}$, which we define as the quotient between the liabilities and equity (data from DATASTREAM).

$R O I_{i t}$ is the return-on-investment for firm i in period $t$, which we define as the quotient between the operating profits and total assets (data from DATASTREAM).

$S I Z E_{i t}$ measures the size of firm $\mathrm{i}$ in period $\mathrm{t}$, and we define it using the asset logarithm (data from DATASTREAM).

$\operatorname{varGDP} P_{t}$ is the percentage variation of Gross Domestic Product (GDP) between year $\mathrm{t}$ and $\mathrm{t}-1$ in the country in which market $\mathrm{j}$ is located (data from World Bank).

$\operatorname{rot} M K T_{j t}$ is a proxy of the liquidity of market $\mathrm{j}$ in period $\mathrm{t}$, which is defined as the quotient between the trade volume and the market capitalization at the end of year $\mathrm{t}$ (data from DATASTREAM).

\section{Conclusions}

The purpose of the study was to understand (1) whether the market's reward (penalty) for meeting (failing to meet) analysts' forecasts significantly differs between markets and (2) whether the magnitude of that reward (penalty) influences the perceived incentive to manage earnings in order to meet forecasts.

Based on a sample of firms listed in six different stock indexes, we find significant differences between markets in terms of their reaction to companies meeting (or failing to meet) earnings forecasts. These differences in stock returns are explained by various features of the markets and the countries in which they are located. Our results show that markets in countries with code law systems, less financial and economic development, more analysts following companies and more accurate forecasts generate the strongest reactions. In each market analysed in the study, we can observe features that stimulate greater reactions and those that could limit reactions. The order of the indexes from most to least reward (penalty) for companies that meet (fail to meet) earnings forecasts depends on a set of variables with effects in opposite directions.

In addition, the results show a positive link between the market's reward (penalty) for stocks that meet (fail to meet) earnings forecasts and the perceived incentive to manage earnings to meet forecasts. The larger the reward or penalty, the more likely firms are to feel motivated to manage their earnings to meet earnings forecasts.

These results do not imply that companies listed in markets with lower rewards or penalties necessarily perceive less incentive to manage earnings, since perceived incentive may be related to diverse goals. However, our results do indicate that the perceived incentive to manage earnings to meet analysts' forecasts, which was examined in numerous prior studies (Callao \& Jarne, 2018; Dechow et al., 2000; Matsumoto, 2002; Payne \& Robb, 2000; Zhang et al., 2018), is stronger in markets in which meeting forecasts is more valued.

Our results are especially relevant for investors, regulators, auditors and analysts. When deciding to invest or divest in markets with a greater reaction to meeting or failing to meet analysts' forecasts, investors should consider that companies who met these forecasts may have done so at least partially through earnings management, not necessarily good business management. Additionally, in light of our findings, regulatory bodies should strive to ensure compliance with regulations and auditors should improve their supervision over firms to limit and detect these management practices, particularly for firms listed in markets in which there is a greater perceived incentive for earnings management. Finally, analysts should be aware of the importance of their forecasts. In many cases, these forecasts become goals to reach, which could encourage earnings management, especially in markets with certain features. In addition, manipulation of reports by analysts may play an important role in influencing companies' behaviour, as emphasised by Ciesielski and Henry (2017).

This research builds upon prior international literature. First, it contributes to the field of event studies by providing an international comparison of the reactions of different markets to companies that meet or fail to meet earnings forecasts, a topic that has not yet been covered. Second, this study builds upon prior studies of earnings management incentives and analysts' forecasts. It proves that the way these forecasts affect firms' motivation to adopt earnings management practices varies across markets based on their reaction to companies who meet or fail to meet earnings forecasts.

Our study has some limitations arising from the inherent qualities of this type of research. The first is the use of discretionary accruals as a way to measure earnings management, as this means that our results are affected by the model we chose to estimate these accruals. Lack of precision and improper specification of accrual models can result in measurement errors. However, our sensitivity analysis shows similar results when a different model was used. Second, this type of study suffers from endogenous problems ${ }^{7}$, which we tried to mitigate by incorporating control variables into the regression.

Future research in this area could analyse forecasted accounting figures other than earnings, since market reactions can be affected by these figures as well.

\section{Funding}

This study was financed by the Regional Government of Aragón in the framework of the Research Group Ref. S33_17R.

\footnotetext{
${ }^{7}$ For more on this issue, see studies like those of Larcker and Rusticus (2010) and Lennox et al. (2012).
} 


\section{Conflict of interests}

The authors declare no conflict of interests.

\section{References}

Abarbanell, J., \& Lehavy, R. (2003a). Biased forecasts or biased earnings? The role of reported earnings in explaining apparent bias and over/under reaction in analystst' earnings forecasts. Journal of Accounting and Economics, 36, 105-146. https://doi.org/10.1016/j.jacceco.2003.11.001

Abarbanell, J., \& Lehavy, R. (2003b). Can stock recommendations predict earnings management and analysts' earnings forecast errors? Journal of Accounting Research, 41 (1), 1-31. https://doi.org/10.1111/1475-679X.00093

Ascioglu, A., Hegde, S., Krishnan, G., \& McDermott, J. (2012). Earnings management and market liquidity. Review of Quantitative Finance and Accounting, 38, 257-274. https://doi.org/10.1007/s11156-010-0225-9

Barton, J., \& Simko, P. (2002). The balance sheet as an earnings management constraint. The Accounting Review, 77, 1-27. https://doi.org/10.2308/accr.2002.77.s-1.1

Bartov, E., Givoly, D., \& Hayn, C. (2002). The rewards to meeting or beating earnings expectations. Journal of Accounting and Economics, 33, 173-204. https://doi.org/10.1016/ S0165-4101(02)00045-9

Barua, A., Hoon, J., \& Yi, S. (2019). Hierarchy of earnings thresholds based on discretionary accruals. Advances in Accounting, 44, 29-48. https://doi.org/10.1016/j.adiac.2018. 12.002

Beck, T., \& Levine, R., (2002). Industry growth and capital allocation: does having a market- or bank-based system matter? Journal of Financial Economics, 64, 147-180. https://doi.org/10.1016/S0304-405X(02)00074-0

Bikky, J., \& Picheng, L. (2002). Earnings management in response to debt covenant violations and debt restructuring. Journal of Accounting, Auditing and Finance, 17 (4), 295-324. https://doi.org/10.1177\%2F0148558X0201700402

Brown, L. (2003). Small negative surprises: frequency and consequence. International Journal of Forecasting, 19, 149159. https://doi.org/10.1016/S0169-2070(02)00061-4

Burgstahler, D., \& Dichev, I. (1997). Earnings Management to Avoid Earnings Decreases and Losses. Journal of Accounting and Economics, 24, 99-126. https://doi.org/10. 1016/S0165-4101(97)00017-7

Burgstahler, D., \& Eames, M. (2006). Management of earnings and analystst forecasts to achieve zero and small positive earnings surprises. Journal of Business, Finance and Accounting, 33 (5\&6), 633-652. https://doi.org/10.1111/j. 1468-5957.2006.00630.X

Callao, S., Jarne, J.I., \& Wroblewski (2014). The development of earnings management research. Review of literature from three different perspectives. Theoretical Journal of Accounting, 79 (135), 135-177.

Callao, S., \& Jarne, J.I. (2018). Los pronósticos de los analistas como incentivo a la manipulación del resultado. Spanish Journal of Finance and Accounting / Revista Española de Financiación y Contabilidad, 47 (1), 124-155. https://doi. org/10.1080/02102412.2017.1371977

Caneghem, T. (2002). Earnings management induced by cognitive reference points. British Accounting Review, 34 (2), 167-178. https://doi.org/10.1006/bare.2002.0190

Charitou, M., Lois, P., \& Santoso, H. B. (2012). The Relationship Between Working Capital Management and Firms Profitability: An Empirical Investigation for an Emerging
Asian Country. International Business \& Economics Research Journal, 11 (8), 839-847. https://doi.org/10.19030/iber. v11i8.7162

Cheng, Q., \& Warfield, T.D. (2005). Equity incentives and earnings management. The Accounting Review, 80 (2), 441476. https://doi.org/10.2308/accr.2005.80.2.441

Chih, H., Shen, C., \& Kang, F. (2007). Corporate Social Responsibility, Investor Protection, and Earnings Management: Some International Evidence. Journal of Business Ethics, 79, 179-198. https://doi.org/10.1007/s10551-007-9383-7

Ciesielski, J., \& Henry, E. (2017). Accountingt's tower of Babel: key considerations in assessing non-GAAP earnings. Financial Analysts Journal, 73 (2), 34-50. https://doi.org/ 10.2469/faj.v73.n2.5

Das, S., \& Zhang, H. (2003). Rounding-up in reported EPS, behavioural thresholds and earnings management. Journal of Accounting and Economics, 35 (1), 31-50. https://doi.org/ 10.1016/S0165-4101(02)00096-4

Dechow, P., Sloan, R., \& Sweeney, A. (1995). Detecting Earnings Management. The Accounting Review, 70 (2), 193225. https://www.jstor.org/stable/248303

Dechow, P., Richardson, S., \& Tuna, A. (2000). Are benchmark beaters doing anything wrong?. Available in SSRN: http://ssrn.com/abstract=222552 or http://dx.doi.org/10. 2139/ssrn.222552

Dechow, P., Ge, W., \& Schrand, C. (2010). Understanding earnings quality: A review of the proxies, their determinants and their consequences. Journal of Accounting and Economics, 50 (2\&3), 344-401. https://doi.org/10.1016/j.jacceco. 2010.09.001

Defond, M., \& Jiambalvo, J. (1994). Debt covenant violation and manipulation of accruals, Journal of Accounting and Economics, 17, 145-176. https://doi.org/10.1016/ 0165-4101(94)90008-6

Degeorge, F., Ding, Y., Jeanjean, T., \& Stolowy, H. (2013). Analyst coverage, earnings management and financial development: An international study. Journal of Accounting and Public Policy, 32, 1-25. https://doi.org/10.1016/j. jaccpubpol.2012.10.003

Dichev, I., Graham, J., Harvey, C., \& Rajgopal, S. (2016). The misrepresentation of earnings. Financial Analysts Journal, 72 (1), 22-35. https://doi.org/10.2469/faj.v72.n1. 4

Djankov, S., McLiesh, C., \& Shleifer, A. (2007). Private credit in 129 countries. Journal of Finance and Economics, 84, 299-329. https://doi.org/10.1016/j.jfineco.2006.03.004

Edmonds, C., Edmonds, J., Fu, R., \& Jenkins, D. (2018). Price momentum and the premium for meeting or beating analysts' forecasts of earnings. Advances in Accounting, 42, 34-47. https://doi.org/10.1016/j.adiac.2018.07.003

Embong, Z., \& Hossini, L. (2018). Analyst Forecast Accuracy and Earnings Management. Asian Journal of Accounting and Governance, 10, 97-108. http://dx.doi.org/10.17576/ AJAG-2018-10-09

Francis, J., LaFond, R., Olsson, P., \& Schipper, K. (2004). Costs of Equity and Earnings Attributes. The Accounting Review, 79 (4), 967-1010. https://doi.org/10.2308/accr.2004. 79.4 .967

García Osma, B, Gill de Albornoz, B and Gisbert, A. (2005). La investigación sobre earnings managements. Spanish Journal of Finance and Accounting, 34 (127), 1001-1033. https://doi.org/10.1080/02102412.2005.10779570

Huang, K., Lao, B., \& McPhee, G. (2017). Does Stock Liquidity Affect Accrual-based Earnings Management?. Journal of Business, Finance \& Accounting, vol, 44 (3\&4), 417- 


\section{7. https://doi.org/10.1111/jbfa.12236}

Iatridis, G., \& Kadorinis, G. (2009). Earnings management and firm financial motives: A financial investigation of UK listed firms. International Review of Financial Analysis, 4, 164173. https://doi.org/10.1016/j.irfa.2009.06.001

Kasznik, R., \& McNichols, M. (2002). Does meeting expectations matter?Evidence from analyst forecast revisions and share prices. Journal of Accounting Research, 40 (3), 727759. https://doi.org/10.1111/1475-679X.00069

Kim, Y., Liu, C., \& Rhee, G. (2003). The Relation of Earnings Management to Firm Size. Working paper, University of Hawai'i, 1-31.

Kinney, W., Burgstahler, D., \& Martin, R. (2002). The materiality of earnings surprise. Journal of Accounting Research, 40 (5), 1297-1329. https://dx.doi.org/10.2139/ssrn. 170560

Kolmogorov, A. (1933). Sulla determinazione empirica di una legge di distribuzione. Inst. Ital. Attuari, Giorn., 4, 8391.

Kothari, S., Leone, A., \& Wasley, C. (2005). Performance matched discretionary accrual measures. Journal of Accounting and Economics, 39 (1), 163-197. https://doi.org/10. 1016/j.jacceco.2004.11.002

Kruskal, W. H., \& Wallis, W. A. (1952). Use of ranks in one-criterion variance analysis. Journal of the American Statistical Association, 47 (260), 583-621. https://doi.org/10. 1080/01621459.1952.10483441

Larcker, D., \& Richardson, S. (2004). Fees paid to audit firms, accrual choices, and corporate governance. Journal of Accounting Research, 42 (3), 625-658. https://doi.org/10. 1111/j.1475-679X.2004.t01-1-00143.x

Larcker, D., \& Rusticus, T. (2010). On the use of instrumental variables in accounting research. Journal of Accounting and Economics, 49, 186-205. https://doi.org/10.1016/j. jacceco.2009.11.004

Larrán, M., \& Rees, W. (1999). Propiedades de los pronósticos de beneficios realizados por los analistas financieros: una aplicación al caso español. Revista Española de Financiación y Contabilidad, 28 (101), 675-729. https://www.jstor.org/ stable/42782201

Lennox, C., Francis, J., \& Wang, Z. (2012). Selection Models in Accounting Research. The Accounting Review, 87 (2), 589-616. https://doi.org/10.2308/accr-10195

Llukani, T. (2013). Earnings management and firm size: an empirical analyze in Albanian market. European Scientific Journal, 9 (16), 135-143.

López, T. and Rees, L. (2002). The effect of beating and missing analystst' forecasts on the information content of unexpected earnings. Journal of Acccounting, Auditing and Finance, 17 (2), 155-184. https://doi.org/10.1177\% 2F0148558X0201700204

Mann, H. B., \& Whitney, D. R. (1947). On a test of whether one of two random variables is stochastically larger than the other. The Annals of Mathematical Statistics, 18, 50-60. https: //www.jstor.org/stable/2236101

Matsumoto, D.A. (2002). Management's incentives to avoid negative earnings surprises. The Accounting Review, 77, 483-514. https://doi.org/10.2308/accr.2002.77.3.483

McNichols, M. (2000). Research design issues in earnings management studies, Journal of Accounting and Public Policy, 19, 313-345. https://doi.org/10.1016/S0278-4254(00) 00018-1

Niskanen, J., \& Keloharju, M. (2000). Earnings cosmetics in tax-driven accounting environment: evidence from Finish public firms. The European Accounting Review, 9 (3), 443-452. https://doi.org/10.1080/09638180020017159

Payne, J., \& Robb, S. (2000). Earnings management: the effect of ex-ante earnings expectations. Journal of Accounting, Auditing and Finance, 15, 415-445. https://doi.org/10. 1177\%2F0148558X0001500401

Plummer, E., \& Mest, D. (2001). Evidence of the management of earnings components. Journal of Accounting, Auditing and Finance, 16, nž 4, 301-323. https://doi.org/ 10.1177\%2F0148558X0101600405

Rosner, R.L. (2003). Earnings manipulation in failing firms. Contemporary Accounting Research, 2, 361-408. https: //doi.org/10.1506/8EVN-9KRB-3AE4-EE81

Shapiro, S.S., \& Wilk, M.B. (1965). An analysis of variance test for normality (Complete samples). Biometrika, 52 (3\&4), 591-611. https://doi.org/10.2307/2333709

Shen, C., \& Chih, H. (2005). Investor protection, prospect theory, and earnings management: An international comparison of the banking industry. Journal of Banking and Finance, 29, 2675-2697. https://doi.org/10.1016/j.jbankfin. 2004.10.004

Siems, M. (2007). Legal Origins: Reconciling Law \& Finance and Comparative Law. McGill Law Journal, 52, 55-81.

Skinner, D., \& Sloan, R. (2002). Earnings surprises, growth expectations and stock returns or don't let an earnings torpedo sink your portfolio. Review of Accounting Studies, 7, 289-312. https://doi.org/10.1023/A:1020294523516

Smirnov, N. V. (1939). On the estimation of the discrepancy between empirical curves of distribution for two independent samples. Bull. Math. Univ. Moscow, 2 (2), 3-14.

Swastika, D.L. (2013). Corporate Governance, Firm Size, and Earnings management: Evidente in Indonesia stock exchange. Journal of Business and Management, 10 (4), 77-82.

Sweeney, A. (1994). Debt covenant violations and managers' accounting responses, Journal of Accounting and Economics, 17, 281-308. https://doi.org/10.1016/ 0165-4101(94)90030-2

White, H. (1980). A heteroscedasticity-consistent covariance matrix estimator and a direct test for heteroscedasticity. Econometrica, 817838. https://doi.org/10.2307/1912934

Zhang, Y., Perols, J., Robinson, D., \& Smith, T. (2018). Earnings management strategies to maintain a string of meeting or beating analyst expectations. Advances in Accounting, 43, 46-55. https://doi.org/10.1016/j.adiac.2018.09.001 
Annex 1: Variables definition

\section{Variables in equation (1)}

mean $\left|C A R_{j t}\right|$ is the variable quantifying the average reward (or penalty) in market $\mathrm{j}$ in period $\mathrm{t}$ for meeting (or failing) to meet earnings forecasts. It is defined as the mean of the absolute values of cumulative abnormal return in a $-1+1$ window around the earnings announcement date for firms listed in index $\mathrm{j}$ in period t. See computation in Annex 2.

$L E G_{j}$ is a dichotomous variable representing the legal system of country $j$, taking value 0 for common law and value 1 for code law, according to the classification by Djankov et al. (2007).

$F I N D E V_{j}$ measures the level of financial development for country $\mathrm{j}$ by the variable Finance-Aggregate taken from Beck and Levine, (2002).

$A F O L L_{i t}$ is the number of analysts following the company $\mathrm{i}$ in period $\mathrm{t}$ ("INC1NET" from I/B/E/S).

$A C C_{i t}$ is the absolute difference between actual earnings ("WC01751" from DATASTREAM) and earnings forecast ("INC1MN" from I/B/E/S) scaled by earnings forecast for company $\mathrm{i}$ in period $\mathrm{t}$.

$l G D P_{j t}$ is the logarithm of GDP per capita for country $\mathrm{j}$ in period $\mathrm{t}$ (data from World Bank).

\section{Variables in equation (2)}

$I T V E_{i t}$ is the variable which represents the incentive of firm $\mathrm{i}$ in period t to manage earnings upward to meet earnings forecasts. Its value will be 1 for firms with the incentive to manage earnings and 0 otherwise. See computation in Annex 2.

mean $\left|C A R_{j t-1}\right|$ is the variable quantifying the average reward (or penalty) in market $\mathrm{j}$ in period $\mathrm{t}-1$ for meeting (or failing) to meet earnings forecasts. It is defined as the mean of the absolute values of cumulative abnormal return in $\mathrm{a}-1+1$ window around the earnings announcement date for firms listed in index $\mathrm{j}$ in period $\mathrm{t}-1$. See computation in Annex 2.

$L I Q_{i t}$ is the liquidity ratio for firm $\mathrm{i}$ in period $\mathrm{t}$, which we define as the quotient between the current assets ("WC02201" from DATASTREAM) and current liabilities ("WC03101" from DATASTREAM).

$S O L V_{i t}$ is the solvency ratio for firm $\mathrm{i}$ in period $\mathrm{t}$, which we define as the quotient between the total assets ("WC02999") and total liabilities ("WC03351") (data extracted from DATASTREAM).

$D E B T_{i t}$ is the debt ratio for firm $\mathrm{i}$ in period $\mathrm{t}$, which we define as the quotient between the liabilities ("WC03351") and equity ("WC03501") (data extracted from DATASTREAM).

$R O I_{i t}$ is the return-on-investment for firm i in period $\mathrm{t}$, which we define as the quotient between the operating profits ("WC01250") and total assets ("WC02999") (data extracted from DATASTREAM).

$S I Z E_{i t}$ measures the size of firm i in period $\mathrm{t}$, and we define it using the asset ("WC02999") logarithm (data extracted from DATASTREAM).

$\operatorname{varGDP} P_{j t}$ is the percentage variation of Gross Domestic Product (GDP) between year t and t- 1 in the country in which market $\mathrm{j}$ is located (data from World Bank)

$\operatorname{rot} M K T_{j t}$ is a proxy of the liquidity of market $\mathrm{j}$ in period $\mathrm{t}$, which is defined as the quotient between the trade volume ("VO") and the market capitalization ("MVC") at the end of year $t$ (data extracted from DATASTREAM) 


\section{Annex 2. Computation of mean $|\mathrm{CAR}|$ and ITVE variables}

\section{mean $|C A R|$ variable}

First, the abnormal return of a share is calculated as the difference between the actual return obtained minus the expected return (equation a).

$$
A R_{i d}=R_{i d}-E R_{i d}
$$

Where:

$A R_{i d}$ is the abnormal return for share i on day $\mathrm{d}$

$R_{i d}$ is the actual return obtained, adjusted for dividends and capital increases, for share i on day $\mathrm{d}$

$$
E R_{i d} \text { is the expected return for share i on day d }
$$

The expected return is obtained from the ordinary leastsquares estimate of the market-model parameters (equation b) for every year from 2006 to 2015 period.

$$
E R_{i d}=\alpha_{i}+\beta_{i} M R_{d}+e_{i}
$$

Where:

$E R_{i d}$ is the expected return for share i on day d.

$M R_{d}$ is the market return on day d, measured by the change in the corresponding index (IBEX, FTSE, DOW, DAX, BOVESPA, HANG-SENG).

$e_{i}$ is the model's error term.

After estimating the model's parameters, we calculated the abnormal return based on equality (c), where $a_{i}$ and $b_{i}$ are the estimated values of parameters $\alpha_{i}$ and $\beta_{i}$ :

$$
A R_{i d}=R_{i d}-\left(a_{i}+b_{i} M R_{d}\right)
$$

The cumulative abnormal return in every stock $\left(\mathrm{CAR}_{\mathrm{i}}\right)$ is obtained by aggregating the abnormal returns in the days on which we observed greater reaction in price of share to the earnings announcement, specifically for the interval $(-1,1)$ (equality d):

$$
C A R_{i}=\sum_{d=-1}^{d=1} A R_{i d}
$$

In model (1), proposed to test the hypothesis $\mathrm{H}_{1}$, we introduced the mean $\left|\mathrm{CAR}_{\mathrm{jt}}\right|$ variable, which is the mean of absolute values of CAR (|CAR|) for the firms listed in market $j$ in period t (equality e). We use the absolute value of CAR because we aim to quantify market reward (CAR would have a positive value) or penalty (CAR would have a negative value).

$$
\text { mean }\left|C A R_{j}\right|=\left(\sum_{i=1}^{n}\left|C A R_{i}\right|\right) / N
$$

Where: $\mathrm{N}$ is the total number of firms in the sample listed in index $\mathrm{j}$.

In equation 2 , proposed to test hypothesis $\mathrm{H}_{2}$, we use mean $\left|C A R_{\text {jt- } 1}\right|$. We introduce the reward (or penalty) with a delay period because the manager's incentive to meet analysts' forecasts will depend on the reaction of the market in the past (t-1).

\section{ITVE variable}

It is a dichotomous variable which identifies the incentive to upwardly manage earnings to meet earnings forecasts (value 1 ). The value is 0 for firms without the incentive to manage earnings upwards to meet forecasts because they meet them without earnings management. The process to assign values 1 or 0 is the following:

We extracted the actual earnings values for the financial period from DATASTREAM and the forecast values for this variable three months before the close date from the I/B/E/S database. We calculated the deviation from actual earnings compared with earnings forecast based on equality ( $f$ ), to arrive at the deviation for each firm and year:

$$
D_{i t}=\left[A E_{i t}-E F_{i t}\right] /\left|E F_{i t}\right|
$$

Where:

$D_{i t}$ is the deviation from actual earnings at the close of the financial period $t$ for firm i compared with the earnings forecast three months previously;

$A E_{i t}$ is the actual earnings for firm $\mathrm{i}$ at the close of year t;

$E F_{i t}$ is the earnings forecast for firm i for the financial period $t$ three months before the close date; and

$\left|E F_{i t}\right|$ is the absolute value of the earnings forecast for firm $i$ for financial period three months before the close date.

From this point, we kept the sample firms for which the deviation is positive ( $D>0$ ), in other words, those for which the actual earnings (AE) exceed earnings forecast (EF).

On the one hand, we identified firms in the set whose earnings exceed the forecast without the need to manipulate, in other words, firms for which meeting the forecasts does not represent an incentive for earnings management. Using discretionary accruals (DA) as an earnings management measure, the part of the earnings that has not been managed would be non-discretionary earnings (NDE), calculated in accordance with equality $(g)$.

$$
N D E_{i t}=A E_{i t}-D A_{i t}
$$

For companies with $N D E_{i t}>E F_{i t}$, they may have managed earnings, but not seeking to meet earnings forecast, because they meet them without managing earnings.

On the other hand, there are companies in which nondiscretionary earnings are below earnings forecast $\left(N D E_{i t}<\right.$ $\left.E F_{i t}\right)$. This is the group of companies for which meeting analysts' forecasts could be an important incentive to manage earnings. Given that non-discretionary earnings are below the forecasts, this incentive would lead firms to manage earnings upwards using positive discretionary accruals $\left(D A_{i t}>0\right)$.

For firms with non-discretionary earnings below the earnings forecast $\left(N D E_{i t}<E F_{i t}\right)$ but with negative discretionary accruals, $\left(D A_{i t}<0\right)$, meeting earnings forecasts is not an objective leading to an incentive for earnings management. As we stated above, these cases have been excluded from the regression given that the $\mathrm{AE}$ will never be more than the $\mathrm{EF}$, in other words never $\mathrm{D}>0$.

Consequently, we define the ITVE variable as a dichotomous variable whose value is 1 for firms in which $N D E_{i t}<E F_{i t}$ 
and $D A_{i t}>0$ (having the incentive to manage earnings upwards to meet forecasts, they do so), and value 0 otherwise, in other words, when $N D E_{i t}>E F_{i t}$ (firms without the incentive to manage earnings upwards to meet analysts' forecasts).

To assign values 1 or 0 to the ITVE variable we must first measure the level of earnings management in the firms in the sample. As mentioned above, we will base this on the estimate of the discretionary accruals (DA).

Discretionary Accruals estimation: We apply the model proposed by Dechow et al. (1995) (equation h) for each index, using the cross-sectional method and covering the years between 2006 and 2015:

$$
\frac{T A_{i t}}{A_{i t-1}}=\alpha_{1} \frac{1}{A_{i t-1}}+\alpha_{2} \frac{\left(\Delta S A L E_{i t}-\Delta R E C_{i t}\right)}{A_{i t-1}}+\alpha_{3} \frac{P P E_{i t}}{A_{i t-1}}+e_{i t}
$$

Where:

$T A_{i t}$ is the total accruals for firm $\mathrm{i}$ in period $\mathrm{t}$, which has been calculated using the difference between actual earnings (AE) and cash flow from operations (CFO): $T A_{i t}=A E_{i t}-C F O_{i t}$.

$\triangle S A L E_{i t}$ is the change in sales for firm $\mathrm{i}$ in period $\mathrm{t}$ compared with $\mathrm{t}-1$.

$\triangle R E C_{i t}$ is the change in receivables for firm $\mathrm{i}$ in period $\mathrm{t}$ compared with $\mathrm{t}-1$.

$P P E_{i t}$ is property, plant and equipment for firm i in period t.

$A_{i t-1}$ is the total assets figure for firm $\mathrm{i}$ in period $\mathrm{t}-1$ and we have used it as a deflator to prevent heteroscedasticity problems ${ }^{8}$.

$e_{i t}$ is the error term for firm $\mathrm{i}$ in period $\mathrm{t}$.

Data were extracted from DATASTREAM.

After estimating the equation (h) parameters, we used these estimated values to predict total accruals for the analysis period (from 2007 to 2015), and to calculate the prediction error based on the equation (i):

$\frac{D A_{i t}}{A_{i t-1}}=\frac{T A_{i t}}{A_{i t-1}}-\left(a_{1} \frac{1}{A_{i t-1}}+a_{2} \frac{\left(\Delta S A L E_{i t}-\Delta R E C_{i t}\right)}{A_{i t-1}}+a_{3} \frac{P P E_{i t}}{A_{i t-1}}\right)$

Where: $D A_{i t}$ is the discretionary accruals for firm $\mathrm{i}$ in period $\mathrm{t}$ and $a_{1}, a_{2}$ and $a_{3}$ are the estimated values of parameters $\alpha_{1}$ to $\alpha_{3}$.

\footnotetext{
${ }^{8}$ We also used the procedure proposed by White (1980) to obtain estimates consistent with the presence of heteroscedasticity.
} 